\title{
RANCANG BANGUN APLIKASI UTS IN ME BERBASIS ANDROID MENGGUNAKAN FLUTTER DENGAN METODE RAPID APPLICATION DEVELOPMENT
}

\author{
I Made Widiarta ${ }^{1}$, M. Julkarnain ${ }^{2}$, Jati Imanulloh ${ }^{3}$ \\ 1,2,3 Teknik Informatika, Universitas Teknologi Sumbawa \\ email: made.widiarta@uts.ac.id ${ }^{1)}$,
}

\begin{abstract}
Abstrak: Universitas Teknologi Sumbawa atau biasa disingkat dengan UTS merupakan salah satu kampus di Indonesia yang mampu memanfaatkan kemajuan teknologi salah satunya pada bidang Teknologi Informasi. Setiap tahunnya UTS menerima ratusan hingga ribuan calon mahasiswa baru. Setiap kali acara RESPEK UTS dilaksanakan, pada hari pertama panitia akan membagikan booklet kepada calon mahasiswa baru yang mengikuti kegiatan tersebut. Anggaran untuk mencetak booklet tersebut sangat besar yaitu sebesar 30 juta rupiah. Penelitian ini bertujuan untuk mendigitalisasi isi dari booklet tersebut agar dapat meminimalisir anggaran. Penelitian ini menggunakan pendekatan campuran (mixed), dan metode pengembangan perangkat lunak yang digunakan adalah SDLC (System Development Life Cycle) model RAD (Rapid Application Development) dan metode pengujian aplikasi beta testing. Proses pemodelannya dengan pendekatan berorientasi objek dan memanfaatkan $U M L$ sebagai tools untuk pengembangan aplikasi. Kesimpulan dari penelitian ini yaitu menghasilkan Aplikasi UTS IN ME Berbasis Android yang mampu memudahkan mahasiswa dalam mengakses informasi dasar seputar kampus Universitas Teknologi Sumbawa.
\end{abstract}

Kata Kunci : Rancang Bangun Aplikasi, Berbasis Android, Flutter, RAD.

Abstract: Sumbawa University of Technology or commonly abbreviated as UTS is one of the campuses in Indonesia that is able to take advantage of technological advances, one of which is in the field of Information Technology. Every year UTS accepts hundreds to thousands of new student candidates. Every time the UTS RESPEK event is held, on the first day the committee will distribute booklets to prospective new students who take part in the activity. The budget for printing the booklet is very large, amounting to 30 million rupiah. This study aims to digitize the contents of the booklet in order to minimize the budget. This research uses a mixed approach, and the software development method used is the SDLC (System Development Life Cycle) RAD (Rapid Application Development) model and the beta testing application testing method. The modeling process uses an object-oriented approach and utilizes UML as a tool for application development. The conclusion of this study is to produce an Android-Based UTS IN ME Application that is able to make it easier for students to access basic information about the Sumbawa University of Technology campus.

Keywords : Application Design, Android Based, Flutter, RAD.

\section{PENDAHULUAN}

Universitas Teknologi Sumbawa atau biasa disingkat dengan UTS adalah salah satu kampus di Indonesia yang mampu memanfaatkan kemajuan teknologi salah satunya pada bidang Teknologi Informasi. Universitas Teknologi Sumbawa memberikan kesempatan kepada seluruh pelajar di Indonesia bahkan dunia untuk dapat melanjutkan pendidikannya. Setiap tahunnya UTS menerima ratusan hingga ribuan calon mahasiswa baru yang diharapkan dapat bermanfaat bagi semesta alam. Sangatlah disayangkan bila jumlah yang besar ini tidak melalui proses kaderisasi yang baik sejak awal.

Orientasi, Sosialisasi, dan Pengenalan Kampus (OSPEK) merupakan momentum bersejarah bagi setiap siswa yang memasuki gerbang perguruan tinggi. OSPEK dengan seluruh rangkaian acaranya merupakan tahap awal pembentukan karakter bagi seorang mahasiswa baru. RESPEK UTS merupakan sebutan khas OSPEK dari kampus elang Universitas Teknologi Sumbawa. Gerbang awal kemahasiswaan berada pada acara ini. Salah satu tujuan dari acara ini adalah, bagaimana dalam waktu yang singkat, mahasiswa dapat merasakan, memahami, serta mengambil poin-poin positif sebagai tonggak awal menjadi mahasiswa yang utuh dalam menjalankan dan mengenyam pendidikan di masa perkuliahan.

Setiap kali acara RESPEK UTS dilaksanakan, pada hari pertama panitia acara akan membagikan booklet kepada calon mahasiswa baru yang mengikuti kegiatan tersebut. Booklet yang dibagikan itu berisikan informasi dasar seputar Kampus yang tentunya akan memberikan kemudahan kepada calon mahasiswa baru dalam mengenal Kampusnya. Anggaran yang dikeluarkan Kampus untuk mencetak booklet ini cukup besar. Pada proposal RESPEK UTS 2019 tertulis anggaran untuk mecetak booklet ini mencapai 30 juta rupiah.

Pandemi Virus Corona COVID-19 yang tersebar sejak akhir desember tahun 2019 menyebabkan acara RESPEK UTS 2020 tidak bisa dilaksanakan secara langsung. Oleh sebab itu, kegiatan RESPEK UTS 2020 diadakan secara daring menggunakan aplikasi Zoom Meeting. Sayangnya pada saat itu Kampus belum bisa menemukan alternatif lain untuk menggantikan booklet yang seharusnya bisa dibagikan kepada calon mahasiswa baru. Sedangkan calon mahasiswa baru Universitas 
Teknologi Sumbawa berasal dari seluruh Indonesia sehingga booklet itu tidak memungkinkan untuk dibagikan secara langsung kepada mereka.

Menanggapi permasalahan tersebut, maka diperlukan alternatif lain yang mampu menggantikan booklet tersebut agar pengenalan Kampus kepada calon mahasiswa baru bisa tersampaikan dengan baik. Maka dari itu penulis membuat sebuah aplikasi UTS IN ME Berbasis Android. Aplikasi UTS IN ME Berbasis Android merupakan aplikasi yang menampung berbagai informasi dasar seputar Kampus Universitas Teknologi Sumbawa yang dapat memberikan pengenalan dasar kepada calon mahasiswa baru. Dengan adanya aplikasi UTS IN ME Berbasis Android ini diharapkan dapat mempermudah calon mahasiswa baru dalam mengakses informasi. Mereka akan dapat mengakses aplikasi tersebut hanya dengan menggunakan smartphone yang dimiliki.

\section{TINJAUAN PUSTAKA}

Media pembelajaran Booklet merupakan kelompok media teknologi cetak. Booklet merupakan buku kecil yang berisikan maksimal sebanyak empat puluh delapan halaman tidak termasuk sampul. Booklet berisi informasi penting, booklet yang isinya harus jelas, tegas, mudah dipahami dan akan lebih menarik jika disertai gambar. Ukurannya yang kecil membuat booklet mudah dibawa kemana-mana. Selain itu, booklet yang berisi informasi penting disertai dengan gambar ilustrasi memudahkan siswa untuk menggunakannya dalam proses pembelajaran.

Android adalah salah satu sistem operasi mobile yang berkembang diantara sistem operasi yang lainnya. Sistem operasi lainnya seperti Windows Mobile, i-Phone OS, Symbian dan masih banyak lagi juga menawarkan kekayaan isi dan keoptimalan berjalan di atas perangkat hardware yang ada. Sistem operasi pada saat ini beroperasi dengan menggunakan aplikasi prioritas yang telah dibuat sendiri tanpa melihat adanya kelebihan dari aplikasi pihak ketiga. Oleh karena itu adanya keterbatasan distribusi aplikasi pihak ketiga untuk platform mereka.

Aplikasi adalah program siap pakai yang dapat digunakan untuk menjalankan perintah dari pengguna aplikasi dengan tujuan untuk mendapatkan hasil yang lebih akurat sesuai dengan tujuan pembuatan aplikasi. komputasi yang diinginkan atau diharapkan dan pemrosesan data yang diharapkan.

Aplikasi Mobile atau sering disingkat Mobile Apps adalah aplikasi perangkat lunak yang dalam pengoperasiannya dapat berjalan di perangkat bergerak (Smartphone, Tablet, iPod, dll), dan memiliki sistem operasi yang mendukung perangkat lunak mandiri. Aplikasi seluler dapat berasal dari aplikasi yang sebelumnya telah diinstal pada perangkat seluler atau dapat juga diunduh melalui situs distribusinya. Secara umum, aplikasi mobile memungkinkan pengguna untuk terhubung ke layanan internet yang biasanya hanya diakses melalui PC atau Notebook.

Flutter adalah software development kit (SDK) buatan Google yang berfungsi untuk membuat aplikasi mobile menggunakan bahasa pemrograman Dart, baik untuk Android maupun iOS. Dengan Flutter, aplikasi Android dan $i O S$ dapat dibuat menggunakan basis kode dan bahasa pemrograman yang sama, yaitu Dart bahasa pemrograman yang juga di produksi oleh Google tahun 2011. Flutter ditujukan untuk mempermudah dan mempercepat proses pengembangan aplikasi mobile yang dapat berjalan di Android dan iOS, tanpa harus mempelajari dua bahasa pemrograman secara terpisah.

Dart adalah sebuah bahasa pemrograman yang dikembangkan oleh Google, dirancang oleh Lars Bak dan Kasper Lund. Dart sudah dikenal pertama kalinya pada tanggal 10 Oktober 2011. Versi 1.0 dari bahasa pemrograman ini baru dirilis pada bulan November 2013. Versi stabil terbaru adalah Dart 2.1, yang dirilis pada tanggal 15 November 2018. Dart dapat digunakan untuk membuat aplikasi server (berbentuk commandline interface), web, maupun mobile (Android dan iOS).

Unified Modeling Language yang selanjutnya disebut $U M L$ adalah teknik pengembangan sistem yang menggunakan bahasa grafis sebagai alat bantu untuk mendokumentasikan dan melakukan spesifikasi sistem. UML pertama kali di populerkan oleh Grady Booch dan James Rumbaugh pada tahun 1994 untuk mengkombinasikan dua metodologi terkenal yaitu Booch dan OMT, kemudian Ivar Jacobson, yang menciptakan Object Oriented Software Engineering (OOSE) ikut bergabung. Standar UML dikelolah oleh Object Management Group (OMG).

Pengujian beta yang dikenal sebagai pengujian pengguna berlangsung di situs pengguna akhir oleh pengguna akhir untuk memvalidasi pengujian kegunaan, fungsionalitas, kompatibilitas, dan keandalan perangkat lunak yang dibuat. Aktifitas pengujian beta menambah nilai siklus hidup pengembangan perangkat lunak karena memungkinkan pelanggan memiliki kesempatan untuk memberikan masukkan ke dalam desain, fungsi, dan kegunaan dari produk. Masukkan ini tidak hanya penting untuk keberhasilan produk tetapi juga investasi ke produk masa depan ketika data yang dikumpulkan dikelola secara efektif. Tujuan utama dari pengujian beta adalah untuk menempatkan aplikasi yang dibuat ke tangan pengguna yang sebenarnya mereka berada di luar tim teknik untuk menemukan setiap kekurangan atau masalah dari perspektif pengguna akhir.

\section{METODE}

Metode penelitian yang digunakan dalam penelitian ini adalah metode campuran (mixed). 
Berikut merupakan gambaran dari seluruh proses yang dilakukan dalam penelitian ini:

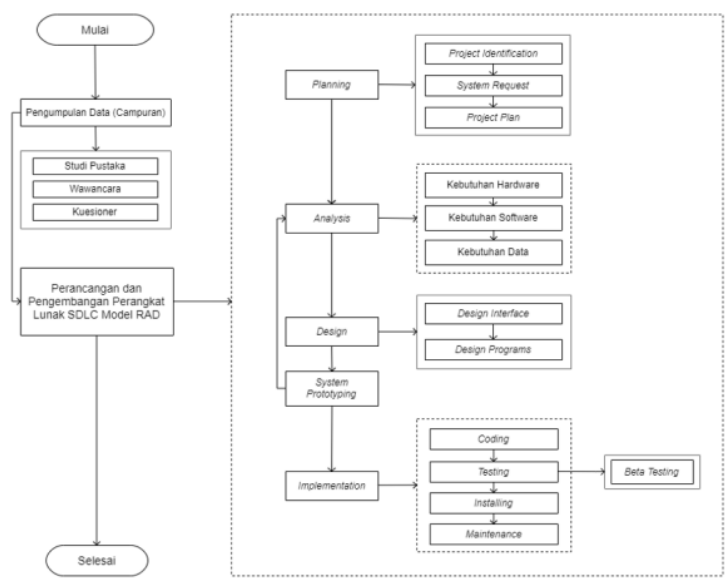

Gambar 1. Alur Metode Penelitian

Metode pengumpulan data yang digunakan dalam penelitian ini adalah metode studi pustaka, wawancara, dan kuesioner dengan penjelasan sebagai berikut:

Studi pustaka dalam penelitian ini dilakukan dengan cara meninjau serta memahami dengan cermat isi dari booklet RESPEK UTS tahun 2019. Kegiatan studi pustaka dilakukan untuk mendapatkan informasi yang diperlukan agar bisa memahami objek yang sedang di teliti dengan baik. Informasi yang didapatkan harus bersifat objektif, nyata dan dapat dipertanggungjawabkan, sehingga data yang akan didapatkan sesuai dan relevan dengan keadaan pada objek penelitian.

Wawancara dilakukan dengan cara mengajukan beberapa pertanyaan untuk mendapatkan informasi yang dibutuhkan, dilakukan secara semiterstruktur dan tatap muka langsung kepada narasumber terpilih yaitu Kepala Tim Penerimaan mahasiswa baru dari Universitas Teknologi Sumbawa. Narasumber dipilih karena beliau beserta tim merupakan pengurus yang bertanggung jawab langsung mulai dari penerimaan mahasiswa baru hingga acara RESPEK UTS selesai dilaksanakan.

Pada penelitian ini penulis melakukan penyebaran angket atau kuesioner secara online dengan menggunakan Google Form. Penyebaran kuesioner ini bertujuan untuk mendapatkan sejumlah data dari Mahassiwa aktif Universitas Teknologi Sumbawa terkait kebutuhan informasi seputar Kampus saat pertama kali menjadi mahasiswa baru. Dengan begitu akan didapatkan keseuaian antara kebutuhan dengan rancangan aplikasi yang akan dibuat.

Perancangan Aplikasi ini menggunakan metode RAD (Rapid Application Development) dengan pendekatan berorientasi objek dan memanfaatkan UML sebagai tools untuk pengembangan Aplikasi berbasis Android. Berikut merupakan diagram dari seluruh tahapan pengembangan perangkat lunak yang akan dilakukan dalam penelitian kali ini:

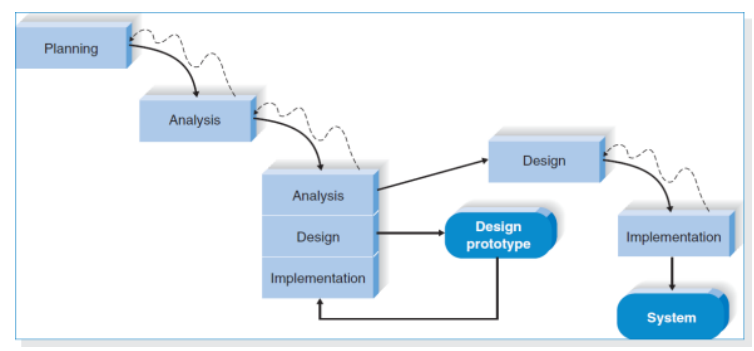

Gambar 2. Metode RAD

Agar alur metode pengembangan perangkat lunak diatas bisa dipahami dengan jelas, penulis telah menguraikan seluruh kegiatan yang dilakukan pada setiap tahapannya sebagai berikut:

Planning merupakan tahap perencanaan paling mendasar yang dilakukan untuk memahami mengapa sistem informasi itu harus dibangun dan bagaimana cara untuk menentukan tim dalam mengerjakan proyek yang akan di tuntaskan. Pada tahap ini akan dilakukan identifikasi pada project digitalisasi booklet RESPEK UTS kedalam bentuk Aplikasi Berbasis Android. Kemudian penulis akan mencari tahu system request seperti apa yang diinginkan oleh Kampus dalam perancangan Aplikasi UTS IN ME Bebrasis Android. Selanjutnya membuat project plan yang akan digunakan untuk mengatur rencana kerja, dan menerapkan teknik bagaimana sistem akan dikembangkan.

Analysis merupakan tahap melakukan pengumpulan data yang akan digunakan pada perancangan aplikasi. Data yang dikumpulkan berupa sumber data primer dan sekunder dilakukan dengan cara melakukan studi pustaka, wawancara dan kuesioner. Selanjutnya melakukan Analisa terhadap data yang telah didapat, mengidentifikasi perancangan aplikasi, serta melakukan pengembangan konsep untuk sistem yang baru.

Penelitian yang dilakukan untuk merancang sistem diperoleh dari pengamatan data-data yang telah didapat. Perancangan sistem di sesuaikan dengan data yang ada dan mengimplementasikan model yang diinginkan oleh pengguna. Pemodelan sistem ini berupa pembuatan use case diagram, activity diagram, dan sequence diagram guna mempermudah dalam proses-proses selanjutnya.

Tahap ini merupakan pembuatan prototype system, yaitu mendefinisikan sistem secara tertulis apa yang bisa dilakukan oleh sistem dan seluruh prosesnya. Tahap ini, sangat melibatkan peran dari pengguna dalam memberikan umpan balik untuk prototipe sistem yang telah dibuat. Jika prototipe dinilai sudah mampu mencukupi kebutuhan dan sesuai dengan keinginan dari pengguna, maka proses dapat dilanjutkan ke tahap Implementation. Namun jika tidak, maka proses dapat diulang kembali ke tahap Analysis dan Design. 
Tahap ini merupakan tahap akhir dari alur penelitian ini. Dimana sistem benar-benar dibangun dan di konstruksikan menggunakan tools dan bahasa pemrograman yang telah direncanakan yaitu Framework Flutter dan Dart sebagai bahasa pemrogramannya. Selanjutnya dilakukan serangkaian pengujian aplikasi dengan menggunakan metode Beta Testing. Pengujian Beta Testing merupakan pengujian terhadap fungsionalitas atau kegunaan dari aplikasi yang telah dibuat, untuk mencari tahu kekurangan atau kesalahan yang terdapat pada aplikasi beserta fungsi-fungsi yang ada sebelum diserahkan kepada user.

\section{HASIL DAN PEMBAHASAN}

\section{Implementasi Program}

Adapun implementasi program pada Aplikasi UTS IN ME Berbasis Android adalah sebagai berikut:

a. Tampilan Icon Aplikasi

Adapun tampilan icon aplikasi pada smartphone pengguna yakni sebagai adalah berikut:

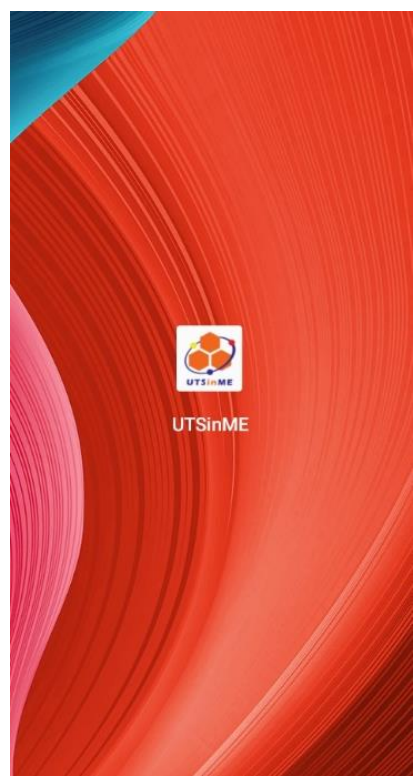

\section{Gambar 3. Tampilan Icon Aplikasi}

Berdasarkan Gambar 3. tampilan icon aplikasi, menampilkan splash screen dari aplikasi UTS IN ME berbasis android, splash screen akan muncul ketika pengguna pertama kali membuka aplikasi dengan mengklik icon yang selanjutnya akan menampilkan antarmuka depan.

b. Tampilan Splash Screen

Adapun tampilan splash screen pada aplikasi UTS IN ME berbasis android adalah sebagai berikut:

\section{Gambar 4. Tampilan Splash Screen}

\section{c. Tampilan Antarmuka Depan}

Adapun tampilan antarmuka depan pada aplikasi UTS IN ME berbasis android adalah sebagai berikut:

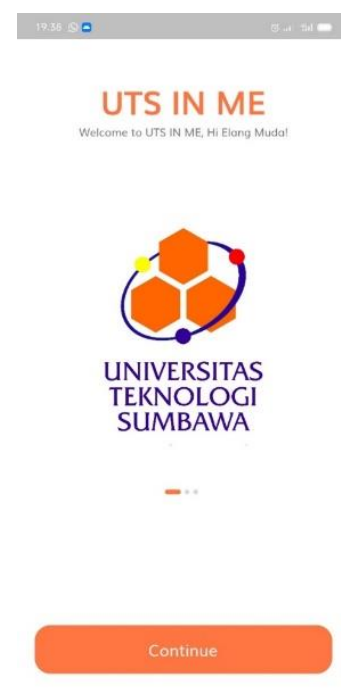

\section{Gambar 5. Tampilan Antarmuka Depan}

Berdasarkan Gambar 5. tampilan antarmuka depan, menampilkan tampilan antarmuka depan dari aplikasi UTS IN ME berbasis android, tampilan antarmuka depan akan muncul setelah splash screen berakhir yang selanjutnya akan menampilkan menu home screen.

\section{d. Tampilan Home Screen}

Adapun tampilan home screen pada aplikasi UTS IN ME berbasis android adalah sebagai berikut: 


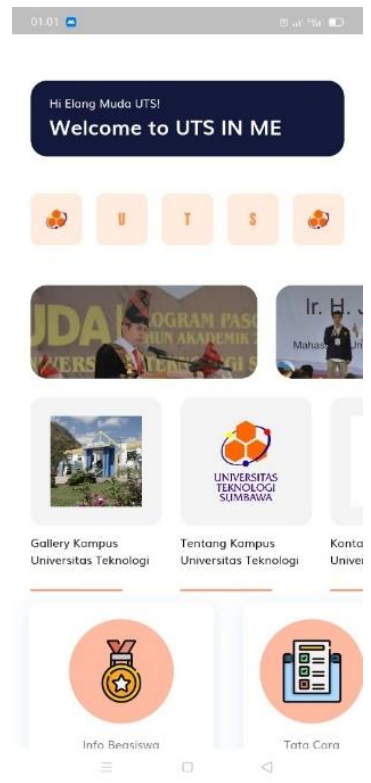

\section{Gambar 6. Tampilan Home Screen}

Berdasarkan Gambar 6. tampilan home screen, menampilkan tampilan home screen dari aplikasi UTS IN ME berbasis android, tampilan menu home screen akan muncul ketika pengguna telah sukses melalui tampilan antarmuka depan. Setelah muncul menu home screen pengguna dapat memilih konten informasi yang ingin ditampilkan.

e. Tampilan Konten Informasi

Adapun tampilan konten informasi pada aplikasi UTS IN ME berbasis android adalah sebagai berikut:

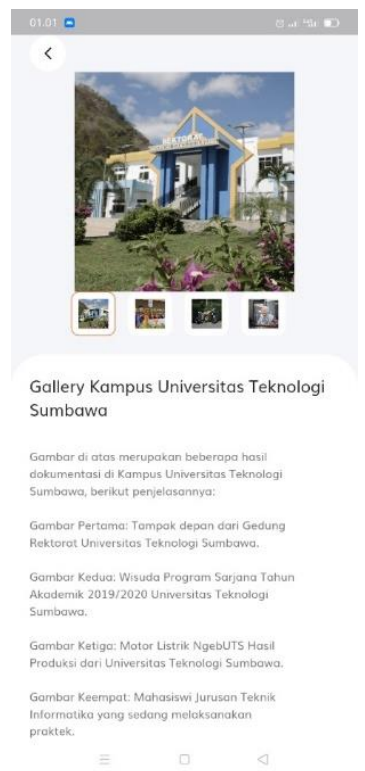

\section{Gambar 7. Tampilan Konten Informasi}

Berdasarkan Gambar 7. tampilan konten informasi, menampilkan tampilan konten informasi dari aplikasi UTS IN ME berbasis android, tampilan konten informasi akan muncul ketika pengguna telah mengklik salah satu konten yang di sediakan pada menu home screen.

\section{KESIMPULAN DAN SARAN}

Aplikasi UTS IN ME Berbasis Android telah berhasil dibangun menggunakan framerwork flutter dan Dart sebagai bahasa pemrogramannya. Aplikasi yang dibangun merupakan aplikasi yang digunakan agar mempermudah mahasiswa Universitas Teknologi Sumbawa dalam mengakses informasi dasar seputar Kampus. Aplikasi UTS IN ME Berbasis Android telah berhasil melewati proses pengujian yakni beta test. Aplikasi yang dibangun memberikan kemudahan kepada pengguna dalam mengakses informasi dasar seputar kampus. Hal ini ditunjukkan oleh hasil pengujian aplikasi pada 30 responden dari mahasiswa aktif menunjukkan bahwa $100 \%$ pengguna merasakan kemudahan dalam mengakses informasi dasar seputar kampus pada Aplikasi UTS IN ME Berbasis Android.

Berdasarkan hasil penelitian ini masih memiliki beberapa kekurangan yakni aplikasi yang masih terbilang statis sehingga pada penelitian selanjutnya memerlukan pengembangan menjadi aplikasi yang dinamis sehingga dapat diakses secara online. Fitur yang terdapat pada aplikasi juga masih sangat belum lengkap dan diharapkan pada penelitian selanjutnya dapat ditambahkan fitur seperti search sehingga pengguna dapat mencari informasi yang ingin dibaca dengan sangat mudah. Aplikasi ini juga perlu ditambahkan fitur favorite sehingga pengguna dapat menyimpan informasi yang suatu saat ingin dibaca kembali.

\section{DAFTAR PUSTAKA}

[1] Ariawan, J., \& Wahyuni, S. (2015). Aplikasi Pengajuan Lembur Karyawan Berbasis Web. Sisfotek Global, 5(1), 1.

[2] Binus University. (2016). Beta Test. https://sis.binus.ac.id/2016/12/16/beta-test/

[3] Saputro, Dendi., Widiarta, IM., \& Julkarnain. M. (2020). Pengembangan Sistem Informasi Pendataan Bedah Rumah Berbasis Web Pada Dinas Perumahan Rakyat dan Kawasan Pemukiman di Kabupaten Sumbawa. Jurnal JINTEKS Vol 2 No. 1. http://jurnal.uts.ac.id/index.php/JINTEKS/articl e/view/561/403

[4] Dennis, A., Wixom, B. H., \& Roth, R. M. (2012). System Analysis and Design 5th Edition. John Wiley \& Sons, Inc.

[5] Developers. (2021). Mengenal Android Studio. https://developer.android.com/studio/intro?hl=i d

[6] Kiki Yasdomi. (2013). Desain Dan Perancangan Sistem Informasi Berbasis Komputer Dalam Pengolahan Data Berobat Pada Balai Pengobatan Ummat Pasir Pengaraian Dengan 
Menggunakan Bahasa Pemograman Visual Basic 6.0. Jurnal Ilmiah Cano Ekonomos, 2(1), 83-97.

[7] Kristanto, V. H. (2018). Metodologi Penelitian Pedoman Penulisan Karya Tulis Ilmiah (KTI). Yogyakarta: CV Budi Utama.

[8] Luthfi, K. (2020). Rancang Bangun Aplikasi Sistem Transaksi Laundry Berbasis Mobile Menggunakan Flutter. Rancang Bangun Aplikasi Sistem Transaksi Laundry Berbasis Mobile Menggunakan Flutter. https://jurnalmahasiswa.unesa.ac.id/index.php/j urnal-manajemeninformatika/article/view/36314/32277

[9] Nugroho, Hendi dan Dion Isnu Eko Nugroho. Perancangan Aplikasi Sistem Absensi Berbasis SMS Gateway, AMIKOM, Yogyakarta, 2010.

[10] Permana, A. Y. (2019). Aplikasi Pengenalan Budaya Reog Ponorogo Berbasis Android. Universitas Muhammadiyah Ponorogo.

[11] Pressman, R. S., \& Maxim, B. R. (2020). Software Engineering: A Practitioner's Approach (9th ed.). McGraw-Hill.

[12] Pralisaputri, Kurnia Ratnadewi Soegiyanto, H., \& Muryani, C. (2016). Pengembangan Media Booklet Berbasis SETS Pada Materi Pokok Mitigasi Dan Adaptasi Bencana Alam Untuk Kelas X Sma. Jurnal GeoEco, 2(2), 147-154.

[13] Rahman, A. (2014). Rancang Bangun Aplikasi Informasi Universitas Bengkulu Sebagai Panduan Pengenalan Kampus Menggunakan Metode Markerless Augmented Reality Berbasis Android. Universitas Bengkulu.

[14] Samuel, H. (2019). Aplikasi Elektronik Majalah Dinding (E-Mading) Universitas Bhayangkara Jakarta Raya Berbasis Android. Universitas Bhayangkara Jakarta Raya.

[15] Sofyan, A. A., Puspitorini, P., \& Yulianto, M. A. (2016). Aplikasi Media Informasi Sekolah Berbasis SMS Gateway Dengan Metode SDLC ( System Development Life Cycle ). Jurnal Sisfotek Global, 6(2), 1-7.

[16] Susanto, R., \& Andriana, D. A. (2016). Perbandingan Model Waterfall dan Prototyping Untuk Pengembangan Sistem Informasi. 14, 6. 